\title{
İRSETCONF
}

\section{ENVIRONMENTAL FACTORS IN ENERGY PRODUCTION OF TURKEY}

\author{
MUHAMMED ERNUR AKINER \\ *Akdeniz University, Vocational School of Technical Sciences, Antalya, Turkey
}

\begin{abstract}
The progress of technology, the increase of the population, increases the speed of energy demand, which is the thought of man to dominate the world. Every energy-generating species has a certain negative effect on the environment. Considering the conservation objective of nature, the Five-Year Development Plan of Turkey consists of the measures are to be taken to develop, disseminate, and take up the greater proportion of consumption in new and renewable energy sources. In order not to face serious problems, it is necessary to give importance to source diversity as soon as possible and to allocate sufficient resources for Research and Development studies to be encouraged to diversify resources, to accelerate the use of alternative energy sources, to encourage such studies. Efforts should be made to efficiently utilize the domestic resource potential in order to lower the percentage of external dependency in the use of energy resources, such activities should be supported, incentives should be given and storage opportunities should be increased. Considering the energy requirement, it is of great importance to prioritize the construction of renewable, nuclear and hydropower facilities in the direction of conservation-use balance, with the aim of not to enter the energy shortage and to minimize natural environmental destruction in the following years. Energy agriculture is an issue that has never been touched. Energy plants in our country should be started with C4 type plants. This study gives answers to what should be the possible energy policy that aims to combine environmental protection and uninterruptible power.
\end{abstract}

Keywords: energy conservation, environmental protection, energy agriculture, energy plants, renewable energy, Turkey

\section{Introduction}

Energy, a vital feature of human life, has evolved to adapt to contemporary human development and needs. The world is rapidly transforming into a global village, depending on the increasing daily energy needs of all the population in the world. Rapid industrialization is 


\section{IRSETCONF}

a debt of energy consumption and currently, most of the world's energy demand is provided by fossil fuel sources. For this reason, the future energy scenario in the world and the phenomenon of global warming lead the world's energy mix to renewable and sustainable energy (RSE) sources (Hosseini \& Wahid, 2016). Renewable energy sources are energy sources from the natural and permanent energy flow occurring in our immediate environment. These include bioenergy, direct solar energy, geothermal energy, hydroelectric, wind and Ocean Energy (tide and wave) (Owusu \& Asumadu-Sarkodie, 2016). Global energy demand and environmental concerns are the driving force for the use of alternative, sustainable and clean energy sources (Hosenuzzaman et al., 2015). The study reviewed opportunities for renewable energy sources in Turkey and some regarding issues such as energy security, energy access, social and economic development, mitigation of climate change and the reduction of environmental and health impacts.

Turkey is one of the energy-intensive economies compared to developed countries, despite the recent progress in energy efficiency. However, Turkey uses energy resources inefficient and consumes more energy to produce a product. During the planned development period, primary energy consumption in Turkey increased significantly due to the increase in economic growth, the development of multi-faceted industrial activities and the change in demographic structures (State Planning Organization, 2001). Turkey aims to carry out studies aimed at improving energy efficiency in selected sectors and areas, spreading existing applications, raising public awareness by announcing sample applications and ultimately contributing to demand-side management (Ministry of Development of Turkey, 2013).

Turkey has a wide spectrum of energy sources such as coal, lignite, asphalt, oil, natural gas, hydro, geothermal, wood, animal and plant wastes, sun and wind. Turkey's national energy production is currently unable to meet its energy supply. The easiest way for Turkey is to develop coal-burning technologies in thermal power plants, in order to increase energy production. However, air pollution is an important environmental problem as confirmed by academic studies on this subject (Kok \& Benli, 2017). One of the most important ways to reduce this negative impact of fossil-based energy resources is undoubtedly the use of renewable energy sources.

There is a strong relationship between energy consumption and economic growth. However, the relationship between renewable electricity consumption and economic development is still not sufficiently explored, and a systematic empirical analysis of this issue is lacking (Asumadu-Sarkodie \& Owusu, 2017). Regulation efforts and commercialization of the power must be spread deep into the entire energy production life cycle (Camilo et al., 2017). Energy strategies can play a crucial role as inputs for decision-making and implementation of measures within the energy policy. This study presented energy strategies to help achieve the 


\section{IRSETCONF}

renewable energy target, thereby reducing emissions, mitigating climate change and providing clean and clean energy for the next generation.

Mitigation of climate change requires a transition from fossil energy sources to renewable energies, and bioenergy products are considered to be one of the potential sources. The structure of energy consumption and the conditions of SOx, NOx and $\mathrm{CO} 2$ emissions affect global changes (acid rain and greenhouse effect) (Bilgen, 2014). Multi-disciplinary perspectives on energy consumption, energy security, and energy policy issues examines the relationship between energy consumption and greenhouse gas emissions (Bauwens, 2016). The fossil fuel consumption in the transport system and the energy-intensive sectors, which are the main pillars of civilization, are associated with the progress of greenhouse gas emissions. Future energy sources are expected to be sustainable, but sustainability of energy production is being discussed because of concerns about inherent competitiveness for the deterioration of the arable land and food and feed markets (Bentsen \& Møller, 2017).

As a promising energy carrier, hydrogen is the perfect candidate for meeting the world's energy demands and at the same time reducing toxic emissions (Hosseini \& Wahid, 2016). The energy supply tool will transform from fossil fuel and nuclear energy into a renewable energy source, and it will be a major transition to success over time, even as the population grows (Ekpeni et al., 2014).

Turkey does not use renewable energy resources efficiently, should encourage new technologies and use all renewable energy potential (Bahadir et al., 2016). Reducing Turkey's dependence on foreign energy, a transition to energy forestry and energy agriculture, obtaining biofuels from these and developing biogas from manure, waste and garbage are important (Sekerci et al., 2017). In Turkey, renewable energy production should be increased in order to increase the country's economic level, reduce foreign dependence and environmental pollution and increase the country's development level. This study offers renewable and sustainable energy policies in Turkey.

\section{Methodology}

This study aims to evaluate Turkey's renewable energy capacity in order to take into account key priorities in Turkey's energy policy. Turkey has limited amounts of fossil fuel, so it is dependent on foreign energy. It is important to reduce Turkey's dependence on foreign energy. The energy policies of the Turkish government should support domestic energy resources and use installed power plants efficiently in Turkey. In order to reduce Turkey's energy production costs and dependence on other countries, coal should be consumed more in the industry and electricity production, which is the most reliable source of internal energy in Turkey (Sekerci et al., 2017). In order to reduce Turkey's energy production costs and dependence on other countries, coal should be consumed more in the industry and electricity 


\section{IRSETCONF}

production, which is the most reliable source of internal energy in Turkey (Bahadir et al., 2016). In a short-term, the Turkish government should develop coal-burning technologies in thermal power plants, thereby increasing energy production and contributing to Turkey's developing economy (Sekerci et al., 2017). By the way, natural gas is an expensive energy source and consumption is high in Turkey (Bahadir et al., 2016).

Primary energy consumption is being increased by approximately 4.5 percent per year and reached 78.8 million tons of oil equivalent. Also, electricity consumption is being increased by 8.2 percent per year and reached 126.8 billion $\mathrm{kWh}$. In order to achieve the expected targets for privatization, transport communications and energy sectors dominated by public capital is being liberalized and arrangements for the participation of the private sector is being continued for a long time (State Planning Organization, 2001).

However, Turkey has a high renewable energy potential, such as biomass, hydroelectric, wind, solar, geothermal energy, but the current utilization rate of these resources is very low. In recent years, hydraulic, solar, geothermal and wind-based energy production has become widespread in Turkey (Sekerci et al., 2017). The transition from a fossil fuel-based energy system to a renewable energy systems-based system is a process in which renewable energy systems penetration should be guided by specific targets in the medium term (Vidal-Amaro et al., 2015). The Turkish government aims to produce $30 \%$ of the country's electricity demand from renewable energy sources and to activate two nuclear power plants with a total installed capacity of approximately 10,000 MW by 2023 (Melikoglu, 2016).

Within the context of EnviroGRIDS project of the European Union (EU), 2050 projections show that electricity consumption from small and medium-sized renewable energy sources, including solar and wind, will account for $15 \%$ of the total, while solar heat will account for about 16\% in Turkey (Basaran et al., 2015). The goal for Turkey should be generating at least double of this value, which means $35 \%$ electricity from renewable energy with the optimal combinations of biomass, hydroelectric, wind, solar, geothermal energy. According to Melikoglu (2016), energy targets are calculated in detail and it has been determined that Turkey should spend an average of USD 61.0 billion on renewable energy sources in order to achieve Vision 2023 energy targets.

EU wants to fulfill its commitments to reduce the $\mathrm{CO} 2$ emissions by 2050, it is very important that renewable energy sources in the electricity sector be rapidly disseminated (Eleftheriadis \& Anagnostopoulou, 2015). Not only EU countries, but also other countries in the world also have achieved a greater awareness of renewable energy use. Non-renewable energy and agriculture per capita have a positive impact on emissions. Beyond that, $\mathrm{CO} 2$ emissions per capita in five North African countries (Algeria, Egypt, Morocco, Sudan, Tunisia) during the period 1980-2011 shows that the agricultural sector in this region is less polluting than other sectors, such as production and transport (Jebli \& Youssef, 2017). Also, policymakers of BRICS 


\section{IRSETCONF}

countries (e.g. Brazil, Russia, India, China, and South Africa) have encouraged renewable energy consumption and strengthen agriculture management to stop global warming (Liu et al., 2015; Liu et al., 2017). Moreover, increasing natural gas and renewable energy consumption reduces CO2 emissions by $0.1641 \%$ and $0.6201 \%$, respectively, by $1 \%$ for BRICS countries (Dong et al., 2017). The Chinese government is expected to achieve large amounts of $\mathrm{CO} 2$ emission reduction potential (approximately $40 \%$ of the total $\mathrm{CO} 2$ emissions present) by adjusting the industrial structure, narrowing the technology gap between regions, promoting market reform and strengthening the environment (Feng et al., 2017).

\section{Hydroelectric energy}

Hydroelectric production does not produce greenhouse gases and is therefore often referred to as a green energy source. Hydropower is considered as a renewable resource since the water that is used to power the turbines is not lost during the process and it can be reused again to produce electricity.

\section{Geothermal energy}

Geothermal energy is a natural source of heat energy from inside the Earth. The interior of the Earth is accessible by drilling, and the gradient is far above the average gradient (Owusu \& Asumadu-Sarkodie, 2016). According to Melikoglu (2017), the potential for geothermal energy in Turkey is estimated at approximately $4500 \mathrm{MW}$. Turkey's geothermal energy board capacity reached 623,9 MW at the end of 2015. Vision 2023 targets were proposed to be modified to increase geothermal energy installed capacity to $1000 \mathrm{MW}$. In this way, the share of geothermal energy in Turkey's installed capacity in 2023 can rise to $0.8 \%$ (Melikoglu, 2017).

\section{Solar energy}

Solar energy technology is obtained from sunlight to produce electricity using photovoltaic (PV) system (Owusu \& Asumadu-Sarkodie, 2016). Photovoltaic (PV) cells are the basic elements to convert solar energy into electricity and the sun provides $3.6 \times 10^{\wedge} 4 \mathrm{TW}$ (Terawatt) power (Hosenuzzaman et al., 2015). PV is a convenient way to capture solar energy, where PV's energy production is increasing steeply. However, the PV system is highly weather dependent. It is self-reliant without adequate capacity storage devices, such as conventional motor generators, such as batteries or backup systems. The reliability of the system increases significantly when it hybrids with the provision of two system storage devices (Bhandari et al., 2015). Hybrid renewable energy system (HRES) shows that artificial intelligence can optimize the system in a good way without long-term weather data. Since PV and wind generator costs are low in recent years, HRES is becoming increasingly popular for 


\section{IRSETCONF}

electricity generation in rural areas (Bhandari et al., 2015). Also, it is possible to achieve greater energy efficiency in solar power plants using sun tracking systems (Mammadov, 2017).

\section{Wind Energy}

Wind energy uses the kinetic energy of moving air. Creation of a global opportunity through international cooperation that supports the developing countries for renewable energy will reduce the cost of renewable energy investments (Owusu \& Asumadu-Sarkodie, 2016). Weitemeyer et al. (2015) claim that $50 \%$ of the electricity demand in Germany can be met by renewable energy systems such as an optimum mix of wind and solar power production without being stored. Turkey should encourage the use of wind energy as a part of the hybrid renewable energy system (HRES) and also as a new potential for the mitigation of climate change.

\section{Biomass Energy}

The energy recovery from biogas has reduced the environmental burden of the regular storage area. The results of many studies confirm that the waste energy (WTE) plant has environmental advantages, energy recovery, and less environmental impact (Leme et al., 2014). Microalgae is also a very eco-friendly material to mitigate greenhouse gas emissions and it produces large quantities of biomass that can be used for biofuels (Maity et al., 2014). Turkey is intensifying its local resource exploration activities, while on the other hand, is trying to exploit renewable energy sources, increase energy efficiency, and stimulate many other potential such as benefiting from the country's geographical location. Biomass is an important potential among renewable energy sources that will have a large share in the near future. It represents a versatile energy source that can be easily stored with biomass and converted into electricity and heat. It also has the potential to be used for variable purposes such as biomass, feed, fuel and bioethanol (Ekpeni et al., 2014).

Biomass energy is a popular renewable energy method in countries with the agricultural infrastructure required for the cultivation of $\mathrm{C} 4$ plants and the cultivation of energy plants. For instance, energy resources are being diversified during post-socialist transformation in favor of energy security of former socialist countries. This led to a rapid increase in the number of agricultural biogas plants and the rate of energy produced from the agricultural biogas as well as the increase in total energy production from the renewable energy systems. Among the former socialist countries, the Czech Republic remains the leader in the production of energy from agricultural biogas (Chodkowska-Miszczuk et al., 2017).

Most of the grass species have 4-carbon compounds, which are called C4 plants, as the first product in photosynthesis (Poudel, M., \& Dunn, 2017). C4 photosynthesis produces almost a 


\section{IRSETCONF}

quarter of all the world's primary productivity, even though it has only a few plants that can compete (Kar et al., 2017). With the ability of high photosynthesis, sugar cane, corn, sweet sorghum, sprouts, oil and sugar crops, which capture the important part of light coming to earth, turn it into organic materials as a source of energy and are much more successful than other plants, have been put forward in recent years and their production has been started for this purpose in contemporary countries. In some studies conducted in our country in previous years, most of these plants, which usually have C4 properties, have been investigated and the hopeful ones have been determined. Energy is the biggest import item in Turkey. Energy problem cannot be solved without planning how the energy plant production areas can be located in field, garden, pasture cultures.

\section{Hydrogen Energy}

Currently, hydrogen production from non-renewable sources in the world is raided. For each ton of hydrogen produced from coal and hydrocarbons, approximately 5 and 2.5 tonnes of carbon is released in the form of CO2, respectively (Hosseini \& Wahid, 2016). Hydrogen is produced at high pressure in gasification of biomass in supercritical water (scwg) as a renewable energy source that can be used as a fuel and it requires a small amount of energy to pressurize the hydrogen in the storage tank (Dincer \& Acar, 2015).

\section{Findings and recommendations}

A substantial portion of the public electricity generation facilities and all distribution assets should be privatized. Turkey should support local production for equipment such as wind terminals and solar panels. The country should provide resource diversity by giving priority to local resources. The use of solar energy should be promoted. Energy activities should be carried out considering environmental dimension. Energy should be provided for consumers in a cost-effective and timely manner (Basaran et al., 2015). External envelope and heating systems surrounding the building should be converted into heat insulated buildings with inadequate insulation to meet the current standards (Ministry of Development of Turkey, 2013). New technologies should be used to identify energy consumption habits. For instance in their study, Urquizo et al. (2018) used an innovative field-based approach to map and monitor heat loss from a group of buildings using thermal images and to identify the energy consumption from an air source.

The main principle in the energy sector must be to meet the continuous and uninterrupted energy demand of the increasing population and the developing economy in a reliable supply system at the lowest possible cost (State Planning Organization, 2001). In order to create a healthy variety of electricity supply, nuclear energy is going to be included among the sources of 


\section{IRSETCONF}

electricity production in Turkey (State Planning Organization, 2006). Turkey can benefit from nuclear energy if it creates a comprehensive nuclear energy plan, creates an appropriate legal framework, and participates in the development of nuclear technology in the domestic industry (Sirin, 2010). Renewable and nuclear energy investments are expected to reach approximately 110 billion US dollars or approximately 90\% of Turkey's estimated energy expenditure by 2023 (Melikoglu, 2016). Nuclear energy is used or planned in 40 countries around the world, but the contribution of nuclear energy to sustainable development remains a contentious area (Gralla et al., 2016). Nuclear and non-nuclear countries showed higher levels of carbon emissions and household consumption compared to countries that plan to use nuclear energy and do not use nuclear energy (Gralla et al., 2017). According to the World Nuclear Association (WNA) data, greenhouse gas emissions from nuclear power plants are lower than renewable energy sources such as solar and biomass, which are the same level as hydroelectric and wind power plants. For example, as shown, the amount of carbon released to generate $1 \mathrm{kWh}$ of electricity is $29 \mathrm{~g}$ for hydroelectric power plants, $39 \mathrm{~g}$ for nuclear power plants, $115 \mathrm{~g}$ for solar power plants, and 1074 g for power plants (Kok \& Benli, 2017). In Turkey, nuclear energy production will significantly reduce dependence on energy production. The discussions on producing electricity with nuclear energy in Turkey are based on the 1970s. Parallel to this economic growth, Turkey's energy demand increased rapidly at the end of 2015 and reached 269 billion kWh. This demand is expected to reach around 425 billion kWh by 2023, as is anticipated by the Ministry of Energy and Natural Resources (Kok \& Benli, 2017). The Akkuyu Nuclear Power Plant (NPP) is planned to produce 35 billion kWh of electricity per year and 34 billion kWh of electricity per year for Sinop NPP production (Kok \& Benli, 2017).

\section{Conclusion}

In Turkey, renewable energy production should be increased in order to increase The main goal of this study was to investigate whether the selection of the renewable energy resources in Turkey is sustainable and how the transition from fossil fuel-based energy sources to renewable energy sources can affect the quality of the weather in a positive way. The extensive use of fossil fuels is considered unsustainable as a result of depletion of supply and the contribution of greenhouse gas emissions to the atmosphere by greenhouse gas emissions to climate change (Maity et al., 2014). Turkey has limited reserves of fossil fuel, so it is dependent on foreign energy. Turkey uses energy resources inefficient also spends more energy to produce a product. The energy policies of the Turkish authority should support national energy resources and use installed power plants efficiently in Turkey.

the country's economic level. This will also lead to independence from foreign investments. The findings suggest that the usage of the sustainable renewable energy leads to the 


\section{IRSEETCONF}

reduction of the greenhouse gases (GHG) emissions, especially the depletion rate of the ozone layer due to carbon dioxide (CO2). Turkey will complete the development of both environmental and economic sense with this development initiative.

Turkey is not rich in energy resources and environmentally friendly energy technologies should be supported. Energy consumption and therefore energy supply at minimum quantity and cost should be the main target within the framework of a sustainable development approach that will support the economic and social development and have a minimal destructive impact on the environment. Beyond renewable energy systems, nuclear energy is seen by the government as a cheap, sustainable, environmentally friendly system. It is an important way to diversify energy types, and reduce dependence on energy.

\section{References}

[1] Asumadu-Sarkodie, S., \& Owusu, P. A. (2017). The impact of energy, agriculture, macroeconomic and human-induced indicators on environmental pollution: evidence from Ghana. Environmental Science and Pollution Research, 24(7), 6622-6633.

[2] Bahadir, A., Yegin, M., \& Polat, F. (2016). Renewable energy policies in Turkey: a case of bioenergy. Journal of Engineering Research and Applied Science, 5(2), 451-457.

[3] Basaran, S. T., Dogru, A. O., Balcik, F. B., Ulugtekin, N. N., Goksel, C., \& Sozen, S. (2015). Assessment of renewable energy potential and policy in Turkey-Toward the acquisition period in European Union. Environmental Science \& Policy, 46, 82-94.

[4] Bauwens, T. (2016). Explaining the diversity of motivations behind community renewable energy. Energy Policy, 93, 278-290.

[5] Bentsen, N. S., \& Møller, I. M. (2017). Solar energy conserved in biomass: Sustainable bioenergy use and reduction of land use change. Renewable and Sustainable Energy Reviews, 71, 954-958.

[6] Bhandari, B., Lee, K. T., Lee, G. Y., Cho, Y. M., \& Ahn, S. H. (2015). Optimization of hybrid renewable energy power systems: A review. International journal of precision engineering and manufacturing-green technology, 2(1), 99-112.

[7] Bilgen, S. (2014). Structure and environmental impact of global energy consumption. Renewable and Sustainable Energy Reviews, 38, 890-902.

[8] Camilo, H. F., Udaeta, M. E. M., Gimenes, A. L. V., \& Grimoni, J. A. B. (2017). Assessment of photovoltaic distributed generation-Issues of grid connected systems through the 


\section{IRSETCONF}

consumer side applied to a case study of Brazil. Renewable and Sustainable Energy Reviews, 71, 712-719.

[9] Chodkowska-Miszczuk, J., Kulla, M., \& Novotný, L. (2017). The role of energy policy in agricultural biogas energy production in Visegrad countries. Bulletin of Geography. Socioeconomic Series, 35(35), 19-34.

[10] Dincer, I., \& Acar, C. (2015). Review and evaluation of hydrogen production methods for better sustainability. International journal of hydrogen energy, 40(34), 11094-11111.

[11]Dong, K., Sun, R., \& Hochman, G. (2017). Do natural gas and renewable energy consumption lead to less $\mathrm{CO} 2$ emission? Empirical evidence from a panel of BRICS countries. Energy, 141, 1466-1478.

[12] Ekpeni, L. E., Benyounis, K. Y., Nkem-Ekpeni, F., Stokes, J., \& Olabi, A. G. (2014). Energy diversity through renewable energy source (RES)-a case study of biomass. Energy Procedia, 61, 1740-1747.

[13] Eleftheriadis, I. M., \& Anagnostopoulou, E. G. (2015). Identifying barriers in the diffusion of renewable energy sources. Energy Policy, 80, 153-164.

[14] Feng, C., Zhang, H., \& Huang, J. B. (2017). The approach to realizing the potential of emissions reduction in China: An implication from data envelopment analysis. Renewable and Sustainable Energy Reviews, 71, 859-872.

[15] Furuoka, F. (2017). Renewable electricity consumption and economic development: New findings from the Baltic countries. Renewable and Sustainable Energy Reviews, 71, 450463.

[16] Gralla, F., Abson, D. J., Møller, A. P., Lang, D. J., \& von Wehrden, H. (2017). Energy transitions and national development indicators: A global review of nuclear energy production. Renewable and Sustainable Energy Reviews, 70, 1251-1265.

[17] Gralla, F., John, B., Abson, D. J., Møller, A. P., Bickel, M., Lang, D. J., \& von Wehrden, H. (2016). The role of sustainability in nuclear energy plans-What do national energy strategies tell us?. Energy Research \& Social Science, 22, 94-106.

[18] Hosenuzzaman, M., Rahim, N. A., Selvaraj, J., Hasanuzzaman, M., Malek, A. A., \& Nahar, A. (2015). Global prospects, progress, policies, and environmental impact of solar photovoltaic power generation. Renewable and Sustainable Energy Reviews, 41, 284-297.

[19] Hosseini, S. E., \& Wahid, M. A. (2016). Hydrogen production from renewable and sustainable energy resources: promising green energy carrier for clean development. Renewable and Sustainable Energy Reviews, 57, 850-866. 


\section{IRSETCONF}

[20] Jebli, M. B., \& Youssef, S. B. (2017). The role of renewable energy and agriculture in reducing $\mathrm{CO} 2$ emissions: Evidence for North Africa countries. Ecological indicators, 74, 295-301.

[21] Kar, S., Kumar, R., Kumar, P., Singh, M., Soni, P. G., Makarana, G., Joshi, D., \& Kushwaha, M. (2017). C4 Photosynthesis and Biomass. Int. J. Curr. Microbiol. App. Sci, 6(3), 15671574.

[22] Kok, B., \& Benli, H. (2017). Energy diversity and nuclear energy for sustainable development in Turkey. Renewable Energy, 111, 870-877.

[23] Leme, M. M. V., Rocha, M. H., Lora, E. E. S., Venturini, O. J., Lopes, B. M., \& Ferreira, C. H. (2014). Techno-economic analysis and environmental impact assessment of energy recovery from Municipal Solid Waste (MSW) in Brazil. Resources, Conservation and Recycling, 87, 8-20.

[24] Liu, X., Zhang, S., \& Bae, J. (2017). The nexus of renewable energy-agricultureenvironment in BRICS. Applied Energy, 204, 489-496.

[25] Liu, Z., Guan, D., Wei, W., Davis, S. J., Ciais, P., Bai, J., ... \& Andres, R. J. (2015). Reduced carbon emission estimates from fossil fuel combustion and cement production in China. Nature, 524(7565), 335.

[26] Maity, J. P., Bundschuh, J., Chen, C. Y., \& Bhattacharya, P. (2014). Microalgae for third generation biofuel production, mitigation of greenhouse gas emissions and wastewater treatment: Present and future perspectives-A mini review. Energy, 78, 104-113.

[27] Mammadov, F. F. (2017). Solar Energy Plants' Sun Tracking Systems' Experimental Results and Energy Calculation. International Journal of Energy Engineering, 7(1), 28-31.

[28] Melikoglu, M. (2016). The role of renewables and nuclear energy in Turkey' s Vision 2023 energy targets: Economic and technical scrutiny. Renewable and Sustainable Energy Reviews, 62, 1-12.

[29] Melikoglu, M. (2017). Geothermal energy in Turkey and around the World: A review of the literature and an analysis based on Turkey's Vision 2023 energy targets. Renewable and Sustainable Energy Reviews, 76, 485-492.

[30] Ministry of Development of Turkey. (2013). 10th Development Plan 2014-2018. Ankara, Turkey.

[31] Owusu, P. A., \& Asumadu-Sarkodie, S. (2016). A review of renewable energy sources, sustainability issues and climate change mitigation. Cogent Engineering, 3(1), 1167990. 


\section{İRSETCONF}

International conference on innovative research in Science Engineering \& Technology

\section{Serbia | Belgrade | December 15-17, 2018}

[32] Poudel, M., \& Dunn, B. (2017). Greenhouse Carbon Dioxide Supplementation.

[33] Sekerci, T., Gultekin, N., \& Dincer, S. K. (2017). Renewable and sustainable energy policies in Turkey: a review. Journal of Engineering Research and Applied Science, 6(2), 680-687.

[34] Sirin, S. M. (2010). An assessment of Turkey's nuclear energy policy in light of South Korea's nuclear experience. Energy Policy, 38(10), 6145-6152.

[35] State Planning Organization (DPT). (2001). Eighth five-year development plan 2001-2005. Ankara, Turkey.

[36] State Planning Organization (DPT). (2006). Ninth Development Plan 2007-2013. Ankara, Turkey.

[37] Urquizo, J., Calderon, C., \& James, P. (2018). Modelling the spatial energy diversity in subcity areas using remote sensors. In 31st International Conference on Efficiency, Cost, Optimization, Simulation and Environmental Impact of Energy System (ECOS 2018). Newcastle University.

[38] Vidal-Amaro, J. J., Østergaard, P. A., \& Sheinbaum-Pardo, C. (2015). Optimal energy mix for transitioning from fossil fuels to renewable energy sources-The case of the Mexican electricity system. Applied Energy, 150, 80-96.

[39] Weitemeyer, S., Kleinhans, D., Vogt, T., \& Agert, C. (2015). Integration of Renewable Energy Sources in future power systems: The role of storage. Renewable Energy, 75, 1420. 